International Journal of Agriculture and Environmental Research

ISSN: 2455-6939

Volume: 07, Issue: 06 "November-December 2021"

\title{
EFFECT OF FERTILIZER LEVELS WITH PLANT GROWTH REGULATOR (GA3) IN WHEAT CROP (Triticum aestivum L.)
}

\author{
B. K. Pandey ${ }^{1}$, N. K. Verma ${ }^{2 *}$, Vashisht Kumar ${ }^{1}$, N. K. Singh ${ }^{5}$, \\ Mamta Yadav ${ }^{3}$ and Dr. U.C. Tripathi ${ }^{4}$ \\ ${ }^{1}$ Department of Agronomy, BNPG College, Rath (Hamirpur) U. P. 210431, India \\ ${ }^{2 *}$ DMI, Ministry of Agriculture and Farmers Welfare, Bhopal \\ ${ }^{3}$ IMD, Bhopal \\ ${ }^{4}$ Asstt Prof. Agricultural Economics, BNPG College, Rath \\ ${ }^{5}$ Department of Animal Husbandry and Dairy Science, BNPG College, Rath \\ *Corresponding Author \\ DOI: https://doi.org/10.51193/IJAER.2021.7610
}

Received: 06 Dec. 2021 / Accepted: 14 Dec. 2021 / Published: 27 Dec. 2021

\begin{abstract}
The most important role of nitrogen in the plant is its presences in the structure of protein, nitrogen is also found in chlorophyll, the green colouring matter of leaves. Chlorophyll enables the plant to transfer energy from sunlight by photosynthesis. Next to nitrogen, phosphorus is the most important nutrient needed by a wheat crop for plant development starting when wheat is just a seedling and continuing all the way to maturity. Adequate potassium results in superior quality of the whole plant due to improved efficiency of photosynthesis, increased resistance to some diseases, and greater water use efficiency, stronger wheat straw and assists in grain filling. Plant hormones play a pivotal role in the regulation of plant growth and development. However, their role becomes more crucial under stress because they also act as stress signaling molecules, response determiners, and regulators. Thus, phytohormones are considered the most critical endogenous substances because they regulate many physiological and developmental processes. A field experiment was conducted during 2019-20 to study the effect of different weed control methods and mulching on growth and yield of chickpea at Brahmanand Post Graduate College, Rath district Hamirpur Uttar Pradesh. As a consequence it was found that highest plant height $(\mathrm{cm})$, fresh weight plant $^{-1}(\mathrm{~g})$, dry weight plant $^{-1}(\mathrm{~g})$ and number of functional leaves plant ${ }^{-1}$ was
\end{abstract}


International Journal of Agriculture and Environmental Research

ISSN: 2455-6939

Volume: 07, Issue: 06 "November-December 2021"

found in application of 120:60:40 (N:P:K) ratio of fertilizer level and this growth put forth maximum value of yield attributing characters and finally yield viz. number of effective tillers, length of ear $(\mathrm{cm})$ test weight $(\mathrm{g})$ and grain yield $\left(\mathrm{q} \mathrm{ha}^{-1}\right)$ followed by other reducing fertilizer levels i.e. 100:50:30, 80:40:20, and control. Application of $1.5 \mathrm{~kg} \mathrm{ha}^{-1}$ was increased significantly these all growth, yield and yield attributing characters in wheat crop as seed treatment before sowing. The minimum value was recorded with control plots, while, the wheat yield also decreased beyond the dose of $1.5 \mathrm{~kg} \mathrm{ha}^{-1}$ application of Gibberlic acid when compared with application of $2.0 \mathrm{~kg} \mathrm{ha}^{-1}$ Gibberlic acid.

Keywords: Fertilizer levels, Gibberlic acid (PGR), wheat, growth and yield

\section{INTRODUCTION}

Wheat (Triticum spp. L.) is classify as a main of cereal crop in several parts of the world; it is the $1^{\text {st }}$ widely plant play an important role in the development of civilization, it has the most regularly traded crop of all edible commodities due to it is easy to stores and transport. Moreover, wheat is considered the essential source of carbohydrates and numerous essential nutrients and nutritive fiber contains $12 \%$ protein, $1.72 \%$ fat, $69.60 \%$ carbohydrate and $27.2 \%$ minerals [1]. According to FAO the total cultivated area of wheat in the world reached about 220.10 million ha in 2016 and the total production exceeded about 749.46 million tonne. However, the total cultivated area in India reached about 29.58 million ha and the total production reached about 99.70 million tonne with a productivity of $33.71 \mathrm{q} / \mathrm{ha}$. Uttar Pradesh is the leading producer of wheat occupying area of 9.75 million hectare with a production 31.88 million tone sharing 32.98 percent of total country's production [2].

An efficient management of fertilizer is an important task to increase wheat yield in India. The effect of balanced nitrogen, phosphorus and potash is more prominent and significant over other fertilizers, as because nitrogen is the integral part of protoplasm, protein and chlorophyll, and results in larger cell size in turn increases plant height and crop yields. Increasing crop yield through adequate fertilization is a pertinent farm management tool. The basic requirement for high yield and quality of wheat is that the plant receives optimum amount of nutrients through the growing season [3]. Therefore, this nutrient is mostly added extraneously in order to supplement their deficiencies in soil for successful crop production.

Per-sowing seed treatments in hormonal substances such as Gibberellic acid $\left(\mathrm{GA}_{3}\right)$ significantly have been shown to increase and encourage the process of seed germination characters and seedling parameters, cell division, hypocotyls growth as well as stand establishment, Gibberellic Acid $\left(\mathrm{GA}_{3}\right)$ is consider the most important growth regulator, which play a vital role in breaks seed dormancy, encourages germination, intermodal length, hypocotyls growth and cell division 
International Journal of Agriculture and Environmental Research

ISSN: 2455-6939

Volume: 07, Issue: 06 "November-December 2021"

and increases the size of leaves. Moreover, $\mathrm{GA}_{3}$ stimulates hydrolytic enzymes that are needed for the degradation of the cells surrounding the radical and thus speeds germination by promoting seedling elongation growth of cereal seeds. Seed soaking can do different methods such as osmopriming, hydropriming, potassium salts, hormones polietylinghlycon, nutritional imbalance, osmotic effects, maximizing nutrient reserves through increased physiological activities, root proliferation and rapid seedling appearance that can product strong plants. However, soil applied fertilizers are often associated with deficiencies of nutrients during periods of critical demands such as reproductive stage as a result of limitations in uptake or restrictions in nutrient delivery [4]. In order to curb the challenge of soil fertility, the majority of wheat farmers use soil applied fertilizer both organic and inorganic to enhance growth and yield. In light of important of wheat and its yield losses owing to less fertility and more stress, a field experiment entitled "Effect of fertilizer levels with plant growth regulator $\left(\mathrm{GA}_{3}\right)$ in wheat crop (Triticum aestivum L.)" during autumn season of 2019-20 at the research farm of Brahmanand Post Graduate College, Rath (Hamirpur) U.P. India, was conducted.

\section{MATERIALS AND METHODS}

The field experiment was conducted at research farm of Brahmanand Post Graduate College, Rath (Hamirpur) U.P. during winter season of 2019-20 in the subtropical zone at latitude and longitudinal range of $79.7^{\circ}$ East and $25.5^{\circ}$ North. It is located at an elevation range of 526 feet's from the mean sea level. The annual rainfall ranges between $875-975 \mathrm{~mm}$, which is received mostly from last week of June to last of September with occasional shower in winter. The soil of the experimental field was Parwa in texture having soil $\mathrm{pH} 7.6$, organic carbon $0.53 \%$, field capacity $17.33 \%$, permanent wilting point $6.8 \%$ and bulk density $1.48 \mathrm{gm} / \mathrm{cm}^{3}$ respectively. The available nitrogen, phosphorous and potassium were $108.8,24.55$ and $123.0 \mathrm{~kg}$ per ha ${ }^{-1}$, respectively. Sixteen combinations of four fertilizer levels (N:P:K) i.e. control, 80:40:20, 100:50:30, and 120:60:40 with four Gibberlic acid level i.e. control, $1 \mathrm{~kg}^{\text {-ha }}, 1.5 \mathrm{~kg}^{\text {-ha }}$ and $2.0 \mathrm{~kg}^{-}$ ha were used for the experiment.

Sowing of seeds of wheat variety PBW-373 was undertaken in the field at crop spacing of 22.5 $\mathrm{cm}$ on $20^{\text {th }}$ October 2019. The fertilizer dose of $\mathrm{N}, \mathrm{P}_{2} \mathrm{O}_{5}$ and $\mathrm{K}_{2} \mathrm{O}$ was applied as per the treatment given per plot. Full dose of phosphosus and potash and half dose of nitrogen was applied before sowing and remaining half dose of nitrogen was applied after weeding. The Gibberlic acid was applied as seed treatment just before sowing. The data collected from the experiment was analysed statistically using the analysis of variance procedure, appropriate for the factorial randomized block design. The test of significance was carried out at 5 per cent level. 
International Journal of Agriculture and Environmental Research

ISSN: 2455-6939

Volume: 07, Issue: 06 "November-December 2021"

\section{RESULTS AND DISCUSSION}

\section{Effect on growth characters:}

Increasing fertilizer levels significantly increased the growth character viz. Plant height, fresh weight plant ${ }^{-1}$, dry weight plant ${ }^{-1}$ and number of functional leaves plant ${ }^{-1}$ at 90 days of crop observations.

Highest value of plant height $(85.54 \mathrm{~cm})$ was measured with 120:60:40 fertilizer level which was increased significantly more over 100:50:30 and 80:40:20 while the smallest plant height (78.35 $\mathrm{cm})$ was measured with fertilizer control plot. Each level of increase in fertilizer level significantly increased the plant height i.e. increasing value of plant height were in order to control, 80:40:20, 100:50:30 120:60:40, respectively. This was due to demand of photosynthetic product to meet the reproductive requirements at the development stage of the plant. For better vegetative growth, nitrogen being an important constitute of protein and it is associated with the activity of every living cell. Thus at higher rate of nitrogen it was observed that plants were taller than lower rates. This might be due to increase in cell size and was finally greater vertical development of plant. The observations are in conformity with the findings of Singh and [5-6]. In case of Gibberlic acid, tallest plant $(89.28 \mathrm{~cm})$ was measured with $2.0 \mathrm{~kg} \mathrm{ha}^{-1}$ dose of Gibberlic acid and it was significantly more over other dose of Gibberlic acid i.e. $1.5 \mathrm{~kg} \mathrm{ha}^{-1}, 1.0$ $\mathrm{kg} \mathrm{ha}^{-1}$ and the control. Each level of increased dose of Gibberlic acid significantly increased the plant height in the observation of 90 DAS. Gibberlic acid significantly increased all physiological parameters in comparison to that of control [7]. Probably, Gibberlic acid stimulated rapid cell division and elongation in plant stems and shoots. Increases in number of internodes were also observed in a number of crops [8-9]. Gibberellins (e.g., $\mathrm{GA}_{3}$ ) primarily enhance cell division in the sub-apical region of the rosette axis, leading to stem elongation which, in turn, promotes the formation of flower buds [10-11].

At 90 days stage of crop, maximum fresh weight plant-1 (122.99 g), dry weight plant-1 (19.73g), number of functional leaves plant ${ }^{-1}$ (39.93) were found with 120:60:40 fertilizer level which were significantly higher over other fertilizers levels viz. 100:50:30 and 80:40:20. Minimum fresh weight plant ${ }^{-1}(82.98 \mathrm{~g})$, dry weight plant $^{-1}(14.04 \mathrm{~g})$ and number of functional leaves plant ${ }^{-1}$ (26.46) were found with the plot which was not nourished with any fertilizer application. These growth parameter were due to better utilization of photosynthates within plant, better cell elongation and its multiplication, the results are in consonance with [12-13]. Regarding Gibberlic acid, maximum fresh weight plant $^{-1}(125.59 \mathrm{~g})$, dry weight plant ${ }^{-1}$ (20.71) and number of functional leaves plant-1 (40.97) were found maximum with application of $2.0 \mathrm{~kg} \mathrm{ha}^{-1}$ Gibberlic acid which was significantly higher over other decreasing doses of Gibberlic acid i.e. $1.5 \mathrm{~kg} \mathrm{ha}^{-1}$ and $1.0 \mathrm{~kg} \mathrm{ha}^{-1}$. Application of Gibberlic acid @ $1.5 \mathrm{~kg} \mathrm{ha}^{-1}$ was also found significantly more 
International Journal of Agriculture and Environmental Research

ISSN: 2455-6939

Volume: 07, Issue: 06 "November-December 2021"

value over $1.0 \mathrm{~kg} \mathrm{ha}^{-1}$ of Gibberlic acid dose and the control. Minimum value for fresh weight plant $^{-1}(107.279 \mathrm{~g})$, dry weight plant ${ }^{-1}$ (17.44) and number of functional leaves plant ${ }^{-1}$ (35.06) were recorded with the plot which was not treated with the Gibberlic acid. It may be due to better regulates process such as seed germination, leaf expansion, stem elongation, flower and trichome initiation, source-sink relationship and flower, fruit and seed development Similar results were reported by [14].

\section{Effect yield attributes and yield:}

Yield attributing characters are the results of increased growth parameter. Yield attributing characters like number of effective tillers plant ${ }^{-1}$, length of ear $(\mathrm{cm})$ and test weight $(\mathrm{g})$ were measured in the trial. Highest number of effective tillers plant ${ }^{-1}(5.67)$, length of ear $(10.40 \mathrm{~cm})$ and test weight $(39.53 \mathrm{~g}$ ) were recorded with 120:60:40 level of fertilizer application, however regarding to the yield attributing characters this level of fertilizer application could not differ significantly from 100:50:30 level fertilizer level which was found statistically at par among each other. The 100:50:30 level of fertilizer application was significantly more over 80:40:20 and the control in this regards. Lowest values for these yield attributing characters were recorded in the control plot where the crop was not flourished with any fertilizer application, [15] reported similar finding. Gibberlic acid also influenced significantly the number of effective tillers plant ${ }^{-1}$, length of ear $(\mathrm{cm})$ and test weight $(\mathrm{g})$ where, highest values were recorded with the application of $1.5 \mathrm{~kg} \mathrm{ha}^{-1}$ Gibberlic acid which was statistically similar to the application of $1.0 \mathrm{~kg} \mathrm{ha}^{-1}$ Giberlic acid. These yield attributing characters significantly decreased when the dose of Gibberlic acid increased beyond $1.5 \mathrm{~kg} \mathrm{ha}^{-1}$ i.e. in the application of $2.0 \mathrm{~kg} \mathrm{ha}^{-1}$ of Gibberlic acid, it may be due to undesirable physiological growth of plant and reduction in yield attributing characters due to over dose of Gibberlic acid. Significantly lowest number of effective tillers plant $^{-1}$, length of ear $(\mathrm{cm})$ and test weight $(\mathrm{g})$ were recorded with the control plot which was not provided the treatment of Gibberlic acid. These results correspond to the findings of [16].

Straw yield and grain yield are the important component to judge of any input efficiency for the any crop both the components are the basic results of enhanced yield attributing characters itself. Highest straw yield $74.68 \mathrm{q} \mathrm{ha}^{-1}$ was calculated with the application of 120:60:40 fertilizer level which was statistically more over other decreased fertilizer levels i.e. 100:50:30 and 80:40:20, while both of these fertilizer levels were calculated significantly more than control one. Regarding to Gibberlic acid the highest straw yield was calculated with the application of $1.5 \mathrm{~kg}$ $\mathrm{ha}^{-1}$ Gibberlic acid which was statistically at par with $1.0 \mathrm{~kg} \mathrm{ha}^{-1}$ application of Gibberlic acid. The straw yield decreased beyond application of $1.5 \mathrm{~kg} \mathrm{ha}^{-1}$ when compared with application of $2.0 \mathrm{~kg} \mathrm{ha}^{-1}$ application of Gibberlic acid. Grain yield was also found in the trend of straw yield, highest grain yield (47.06 q ha-1) was calculated in the application of 120:60:40 fertilizers level 
which was significantly more over other fertilizer levels including control, this level of fertilizer application increased $4.71 \%, 13.93 \%$ and $50.78 \%$ more grain yield. Gibberlic acid was also influenced and increased grain yield significantly up to application of $1.5 \mathrm{~kg} \mathrm{ha}^{-1}$, where the grain yield was calculated $45.99 \mathrm{q} \mathrm{ha}^{-1}$, but it was significantly at par with the application of 1.0 $\mathrm{kg} \mathrm{ha}^{-1}$ Gibberlic acid and 6.82 per cent more over the application of $2.0 \mathrm{~kg} \mathrm{ha}^{-1}$ Gibberlic acid. The lowest seed yield $\left(41.74 \mathrm{q} \mathrm{ha}^{-1}\right)$ was calculated with the control plot similar result was produced by [17]. 
Table 1: Growth parameters and yield attributes influenced by fertilizer levels and Gibberlic acid

\begin{tabular}{|c|c|c|c|c|c|c|c|c|c|c|}
\hline Treatment & $\begin{array}{l}\text { Height } \\
\text { of plant } \\
(\mathrm{cm}) \text { at } \\
90 \text { DAS }\end{array}$ & $\begin{array}{l}\text { Fresh } \\
\text { weight }^{-} \\
\text {plant }^{-1} \\
\text { at } 90 \\
\text { DAS }\end{array}$ & $\begin{array}{l}\text { Dry } \\
\text { weight } \\
\text { plant }^{-1} \\
\text { at } \quad 90 \\
\text { DAS }\end{array}$ & $\begin{array}{l}\text { Number } \\
\text { of } \\
\text { functional } \\
\text { leaves } \\
\text { plant }^{-1} \text { at } \\
90 \text { DAS }\end{array}$ & 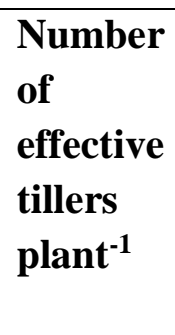 & $\begin{array}{l}\begin{array}{l}\text { Length } \\
\text { of ear } \\
(\mathrm{cm}) \text { and }\end{array} \\
\text { at } \\
\text { harvest } \\
\text { time }\end{array}$ & $\begin{array}{l}\text { Test } \\
\text { weight (g) } \\
\text { after } \\
\text { threshing }\end{array}$ & $\begin{array}{l}\text { Straw } \\
\text { yield } \\
\left(\mathbf{q} \mathbf{h a}^{-1}\right)\end{array}$ & $\begin{array}{l}\text { Grain } \\
\text { yield } \\
\left(\mathbf{q} \mathbf{h a}^{-1}\right)\end{array}$ & Net Profit (Rs.) \\
\hline \multicolumn{11}{|c|}{ Fertilizer levels } \\
\hline Control & 78.35 & 82.98 & 14.04 & 26.46 & 4.15 & 7.62 & 22.42 & 50.47 & 23.16 & 45536.65 \\
\hline $80: 40: 20$ & 80.90 & 111.56 & 18.62 & 35.68 & 5.67 & 9.90 & 38.90 & 64.76 & 40.50 & 77721.32 \\
\hline $100: 50: 30$ & 83.30 & 117.92 & 19.05 & 37.74 & 5.59 & 10.22 & 39.30 & 70.58 & 44.84 & 87278.99 \\
\hline $120: 60: 40$ & 85.54 & 122.99 & 19.73 & 39.93 & 5.67 & 10.40 & 39.53 & 74.68 & 47.06 & 91574.35 \\
\hline S.E. $(d) \pm$ & 0.866 & 1.516 & 0.246 & 0.531 & 0.119 & 0.119 & 0.108 & 0.724 & 0.505 & \\
\hline C.D. at $5 \%$ & 1.25 & 4.38 & 0.71 & 1.53 & 0.34 & 0.34 & 0.31 & 2.09 & 1.46 & \\
\hline \multicolumn{11}{|c|}{ Gibberlic acid (GA3) doses } \\
\hline Control & 68.44 & 107.27 & 17.44 & 35.06 & 4.14 & 9.28 & 38.23 & 69.86 & 41.74 & 74750.39 \\
\hline $1.0 \mathrm{~kg} \mathrm{ha}^{-1}$ & 76.88 & 115.59 & 18.12 & 36.68 & 5.50 & 10.49 & 39.48 & 74.28 & 45.70 & 82907.38 \\
\hline $1.5 \mathrm{~kg} \mathrm{ha}^{-1}$ & 83.01 & 120.41 & 19.28 & 38.90 & 5.71 & 10.51 & 39.55 & 74.21 & 46.14 & 83677.54 \\
\hline $2.0 \mathrm{~kg} \mathrm{ha}^{-1}$ & 89.28 & 125.59 & 20.71 & 40.97 & 3.73 & 10.25 & 39.30 & 71.15 & 42.99 & 81775.99 \\
\hline S.E. (d) \pm & 0.866 & 1.516 & 0.246 & 0.531 & 0.119 & 0.119 & 0.108 & 0.724 & 0.505 & \\
\hline C.D. at $5 \%$ & 1.25 & 4.38 & 0.71 & 1.53 & 0.34 & 0.34 & 0.31 & 2.09 & 1.46 & \\
\hline
\end{tabular}




\section{International Journal of Agriculture and Environmental Research}

ISSN: 2455-6939

Volume: 07, Issue: 06 "November-December 2021"

\section{Table 2: Meteorological data}

\begin{tabular}{|c|c|c|c|c|c|c|c|c|c|c|c|c|c|c|c|c|c|c|c|c|c|c|c|c|c|c|c|}
\hline \multicolumn{2}{|c|}{$\begin{array}{l}\text { Standard } \\
\text { meteorological } \\
\text { week }\end{array}$} & 40 & 41 & 42 & 43 & 44 & 45 & 46 & 47 & 48 & 49 & 50 & 51 & 52 & 1 & 2 & 3 & 4 & 5 & 6 & 7 & 8 & 9 & 10 & 11 & 12 & 13 \\
\hline \multirow[t]{2}{*}{$\begin{array}{l}\text { Temperat } \\
\text { ure }\left({ }^{0} \mathrm{C}\right)\end{array}$} & $\begin{array}{l}\mathrm{Ma} \\
\mathrm{X}\end{array}$ & $\begin{array}{l}35 . \\
8\end{array}$ & $\begin{array}{l}34 . \\
6\end{array}$ & $\begin{array}{l}34 . \\
8\end{array}$ & $\begin{array}{l}33 . \\
6\end{array}$ & $\begin{array}{l}32 . \\
1\end{array}$ & $\begin{array}{l}29 . \\
4\end{array}$ & 3.9 & 3.2 & $\begin{array}{l}26 . \\
5\end{array}$ & $\begin{array}{l}25 . \\
7\end{array}$ & $\begin{array}{l}22 . \\
9\end{array}$ & $\begin{array}{l}22 . \\
8\end{array}$ & $\begin{array}{l}21 . \\
9\end{array}$ & $\begin{array}{l}23 . \\
6\end{array}$ & $\begin{array}{l}21 . \\
2\end{array}$ & $\begin{array}{l}22 . \\
9\end{array}$ & $\begin{array}{l}21 . \\
4\end{array}$ & $\begin{array}{l}21 . \\
5\end{array}$ & 22 & $\begin{array}{l}23 . \\
5\end{array}$ & $\begin{array}{l}27 . \\
3\end{array}$ & $\begin{array}{l}23 . \\
3\end{array}$ & $\begin{array}{l}26 . \\
4\end{array}$ & 28 & $\begin{array}{l}32 . \\
2\end{array}$ & $\begin{array}{l}35 . \\
6\end{array}$ \\
\hline & $\begin{array}{l}\mathrm{Mi} \\
\mathrm{n}\end{array}$ & 20 & $\begin{array}{l}18 . \\
3\end{array}$ & $\begin{array}{l}15 . \\
9\end{array}$ & $\begin{array}{l}14 . \\
9\end{array}$ & $\begin{array}{l}14 . \\
5\end{array}$ & $\begin{array}{l}11 . \\
1\end{array}$ & $\begin{array}{l}11 . \\
9\end{array}$ & $\begin{array}{l}11 . \\
4\end{array}$ & 9.8 & 8.1 & 7.0 & 4.8 & 4.8 & 5.8 & 5.1 & 4.8 & 8.2 & 5.9 & 7.7 & 9.5 & 11 & 9.4 & $\begin{array}{l}11 . \\
7\end{array}$ & $\begin{array}{l}12 . \\
3\end{array}$ & $\begin{array}{l}14 . \\
1\end{array}$ & $\begin{array}{l}16 \\
4\end{array}$ \\
\hline \multirow{2}{*}{$\begin{array}{l}\text { Relative } \\
\text { Humidity } \\
(\%)\end{array}$} & I & 80 & 79 & 76 & 75 & 78 & 79 & 83 & 81 & 81 & 78 & 87 & 90 & 91 & 88 & 88 & 90 & 90 & 89 & 89 & 90 & 83 & 89 & 82 & 80 & 75 & 63 \\
\hline & & 36 & 36 & 36 & 38 & 43 & 47 & 46 & 44 & 44 & 43 & 46 & 49 & 56 & 48 & 52 & 45 & 55 & 58 & 57 & 45 & 47 & 52 & 44 & 43 & 38 & 33 \\
\hline \multicolumn{2}{|c|}{ Rainfall (mm) } & 0 & 0 & 0 & 0 & 0 & 0 & 0 & 0 & 0 & 0 & 0 & 0 & 0 & 0 & 0 & 0 & 0 & 0 & $\begin{array}{l}12 . \\
4\end{array}$ & 0.4 & 0 & 3.2 & 0 & 0 & 0 & 0 \\
\hline \multicolumn{2}{|c|}{$\begin{array}{l}\text { Evaporation } \\
(\mathrm{mm})\end{array}$} & 5.3 & 5.3 & 5.3 & 5.1 & 4.4 & 4.4 & 3.9 & 3.6 & 3.6 & 3.3 & 0.7 & 2.7 & 2.3 & 2.6 & 2.4 & 2.5 & 2.4 & 2.5 & 2.7 & 2.8 & 3.8 & 4 & 4.4 & 5 & 6 & 7.6 \\
\hline
\end{tabular}

$40^{\text {th }}$ Weed- $1^{\text {st }}$ Oct to $7^{\text {th }}$ Oct, $201913^{\text {th }}$ week- $25^{\text {th }}$ March to $1^{\text {st }}$ April, 2020 
International Journal of Agriculture and Environmental Research

ISSN: 2455-6939

Volume: 07, Issue: 06 "November-December 2021"

\section{Net profit:}

It is necessary to compare the performance of various treatment combinations in terms of economics which is important for the agriculturist in general. Highest net profit Rs. 91574.40 was calculated with the application of 120:60:40 fertilizers level which was found Rs. 4295.36 more over 100:50:30 fertilizer level, Rs. 13853.03 mover over 80:40:20 fertilizer level and Rs. 46037.70 more over control. In concern to the Gibberlic acid the highest net profit Rs. 83677.50 was calculated with the application of $1.5 \mathrm{~kg} \mathrm{ha}^{-1}$ Gibberlic acid, this net profit were decreased Rs. 1901.55, Rs. 1131.39 and Rs. 7025.60 when compared with the application of $2.0 \mathrm{~kg} \mathrm{ha}^{-1}$, $1.0 \mathrm{~kg} \mathrm{ha}^{-1}$ and the control application of Gibberlic acid.

\section{METEOROLOGICAL OBSERVATIONS}

Weather that is comfortable for humans is also good for wheat. Wheat needs 12 to 15 inches ( 31 to 38 centimeters) of water to produce a good crop. It grows best when temperatures are warm, from $70^{\circ}$ to $75^{\circ} \mathrm{F}\left(21^{\circ}\right.$ to $24^{\circ} \mathrm{C}$ ), but not too hot. Wheat also needs a lot of rainfall, especially when the crop in initial growth. During the year (2019-20) the total rainfall was above normal during cropping period, the rainfall from September to February was as high as $16.00 \mathrm{~mm}$ which was much lower from normal of $125.50 \mathrm{~mm}$. However proper irrigation facilities were available at research farm and the crop was irrigated as per schedule. During the crop growth period in 2019-20 the lowest and highest mean temperature recorded $5.1^{\circ} \mathrm{C}$ and $35.6^{\circ} \mathrm{C}$ but during the peak growth stage of crop it was not exceeded beyond $28^{0} \mathrm{C}$ which is quite favourable for wheat growth. Relative humidity is one of the most important constraints for wheat growth which must be in the range of 80-90 percent. Highest humidity was recorded in the month of January and February 2020 which was in the range of $88-90$ and it is most favourable humidity for the wheat growth. Similar findings were presented by [18].

\section{CONCLUSION}

The present investigations were carried out with a purpose to assess the adoption of adequate fertilizer level and Gibberlic acid in wheat crop in terms of technical feasibility and yield. The findings of the study are encouraging to adopt application of 120:60:40 (N:P:K) fertilizer level along with the application of Gibberlic acid @ $1.5 \mathrm{~kg}$ ha-1 in wheat crop for obtaining higher seed yield and net profit.

\section{REFERENCES}

[1] BARI (Bangladesh Agricultural Research Institute). 2000. BARI Annual Internal Review for 1999. XIX. RiceWheat Farming System. October 9-12, 2000. 
International Journal of Agriculture and Environmental Research

ISSN: 2455-6939

Volume: 07, Issue: 06 "November-December 2021"

[2] Agricultural Statistics at a Glance (2018). Wheat production in Agriculture At A Glance. PP. 76-79

[3] Behera, A.K. (1995). Effect of seed rate, row spacing and fertilizer on wheat. Indian J. Agron. 40: 51-511.

[4] Meera, S. and Poonam, S. (2010). Response of growth regulators on some physiological traits and yield of wheat (Triticum aestivum L.). Prog. Agric. 10(2): 387-388.

[5] Ghosh, P.K.; Bandyopadhyay, K.K.; Tripathi, A.K.; Hati, K.M.; Mandal, K.G.; and Misra, A.K. (2003). Effect of integrated management of farmyard manure, phosphocompost, poultry manure and inorganic fertilizers for rainfed sorghum (Sorghum bicolor) in Vertisols of central India. Indian Journal of Agronomy. 48 (1) 48-52.

[6] Sobh, M. M.; Sharshar, M. S. and Soad, A. E. (2000). Response of wheat to nitrogen and potassium application in a salt affected soil. Journal of Product and Development, 5 (1) 83-98.

[7] Meera, S. and Poonam, S. (2010). Response of growth regulators on some physiological traits and yield of wheat (Triticum aestivum L.). Prog. Agric. 10(2): 387-388.

[8] Hernandez, P. (1997). Morphogenesis in sunflower as affected by exogenous application of plant growth regulators. Agriscientia, 13: 3-11.

[9] Bagatharia, S.B and S.V. Chanda. 1998. Modification of cell wall polysaccharides during cell elongation in Phasealus vulgaris hypocotyls. Acta Plant Physiol. 20(1): 15-18.

[10] Salisbury, F.B. 1983. The Flowering Process. Pergamon Press, Oxford, UK. 172-218.

[11] Farooqi, A.H.A.; Kumar, R.; Sharma, S.; and Kumar, S.; (1999). Effect of plant growth regulators on flowering behaviour of pyrethrum (Chrysanthemum Cinerariaefolium) in northern Indian plains. J. of Medicinal and Aromatic Plant Sci., 21: 681-685.

[12] Chaturvedi, I. (2006). Effects of different nitrogen levels on growth, yield and nutrient uptake of wheat (Triticum aestivum L.) Internet J. agric. Sci. 2 (2) 372-374.

[13] Tiwari, A.; Rai, O. P.; Singh, G.; Kumar, M.; Pandey, D. and Harikesh (2017) Studies on Influence of Nitrogen and Weed Management on Growth Characters of Late Sown Wheat (Triticum aestivum L.). Int.J.Curr.Microbiol.App.Sci. 6 (11) 2087-2093.

[14] Yamaguchi, S. (2008). Gibberellin metabolism and its regulation. Annu. Rev. Plant Biol. 59, 225-251. doi: 10.1146/annurev.arplant.59.032607.092804.

[15] Shekoofa, A. and Emam, Y. (2008). Effect of nitrogen fertilization and plant growth regulators on yield of wheat (Triticum aestivum L.) cv. Shiraz J. Agric. Sci.Technol. (10) 101-108.

[16] Iqbal, N.; Nazar, R.; Khan, M. I. R.; Masood, A.; and Khan, N. A. (2011). Role of gibberellins in regulation of source-sink relations under optimal and limiting environmental conditions. Curr. Sci. 100, 998-1007. 
International Journal of Agriculture and Environmental Research

ISSN: 2455-6939

Volume: 07, Issue: 06 "November-December 2021"

[17] Gurmani, A. R.; Bano, A.; Muhammad, S. (2006). Effect of growth regulators on growth, yield and ions accumulation of rice (Oryza sativa L.) under salt stress. Pak. J. Bot. 38 (5) 1415-1424.

[18] Mall, R.K. (2000). Wheat yield forecast models based on meteorological parameters. Journal of Agrometeorology. 2 (1): 83-87. 